\title{
SOCIAL AND ECONOMIC BENEFITS OF WORKERS IN INDUSTRIAL COOPERATIVE
}

\author{
Dr. C K GOMATHY, Mr. D. Sravan Kumar, Mr. Ch. Manoj Kumar, Mr. Ch Venkata Mohith \\ Sri Chandrasekharendra Saraswathi Viswa Mahavidyalaya, Kanchipuram
}

\section{I.ABSTRACT:}

The impact of cooperatives on socioeconomic growth is discussed in this work. It is based on a countrywide survey that included a sample of 173 cooperatives and 831 cooperative members. The research was conducted using a semi-structured questionnaire.

It spanned a ten-year period (2001-2011). The survey's findings show that cooperatives have made significant contributions to the country's economic development in addition to supporting their members by providing a variety of products, services, and benefits such as food security, increased income, improved life style and social participation, and inputs for their agricultural. Furthermore, cooperatives support nearly 15.00 to 29.68 decent jobs on average and spent 28,032.29 to 122,297.7 birr per cooperative per year on wages and salaries. Cooperatives' average contribution to Ethiopian GDP during the last 10 years has been determined to be quite low, ranging from 1.21 percent to 12.27 percent.

Cooperatives have failed to make an impact on the socio-economic development of their communities, as evidenced by this study. Country and assist their members in improving their living conditions as a result of the unpaved economy the country's policy

KEYWORDS: Cooperatives, Socio-economic Development, Women's and Youth Empowerment

\section{INTRODUCTION}

Workers cooperatives are businesses in which workers share in the profits and have majority control over the enterprise. Control is exercised democratically on the basis of one person, one role, membership is open to all workers as much as possible, and the return on capital invested in the enterprises is limited.

Over time, capital has hired labour and treated it like any other expendable factor of production; capital has explored labour and subjected it to profit maximisation imperialism; capital has claimed all authority and all profits while disclaiming full liability for the enterprise's debts . But now, workers want all of that to change, and there has been a change; labour will now live alongside capital.

Producing durable and nourishing goods, additivefree goods that aren't highly processed snacks, adopting methods of production that aren't polluting, refusing to produce war-related material or deal with government practises, and racial segregation are just a few examples. These workerowned industrial cooperatives have both social and economic goals.

\section{THE STUDY'S BACKGROUND}

Anambra state's cooperative development history can be traced all the way back to Nigeria. The agricultural development agents first appeared in 
the early 1930s. Agricultural development agents in western Nigeria began organising cocoa producers into tiny co-operative organisations at this time.

Between those times, efforts were undertaken to form a cooperative division. This was before it became too long. It was possible to create an enviable and viable cooperative division. The division was technically under the ministry of local government, but it changed hands multiple times due to resettlements and government changes. The ministry of trade and industries finally approved it.

The estate received 685 co-operative societies with a total membership of 15,155 from the former Eastern state. Individual aspirations and government encouragement, together with the interest benefits desired from the formation of co-operatives, have raised the number of co-operatives in the state to 2,757 , with a total membership of 86,812 .

\section{SCOPE OF THE STUDY:}

Without a doubt, the topic is social, and it makes for a fascinating research project. However, several unavoidable factors, one of which is time contracts, may obstruct its thorough examination. The research was conducted in accordance with standard academic procedures, making more vivid grassroots research findings extremely challenging. Aside from the fact that lecture schedules made doing desk interviews problematic, one had to deal with the dissatisfaction or annoying bureaucratic arrangements of the workers in issue. Another issue that plagued the research project's execution was the willingness and unwillingness of Inyaba farm officials to reveal important information, even those who were kind enough to grant a big interview. Some questions were addressed with reservations, prohibiting one from learning facts and discovering information about the farm.

\section{LIMITATIONS OF THE STUDY}

Farm was numerous, as explained in the prevision subheading. Despite the fact that considerable attempts were made to elevate. All of these stumbling blocks. There are two types of problems that can be encountered: natural and man-made. The formal issues include the issues of time, age, and distance, as well as the absence of necessary funding and a partial lack of current records on the part of society.

However, the amount of time available was limited in comparison to the amount of work to be completed. As a result, more effort will be made to cram as much study time as possible into the allocated period. The problem of society's remoteness from our school cannot be solved through bribery. So our only alternative was to ensure that if we convey ourselves to society, we must then endeavour to achieve a great deal before returning to school for training.

Moreover. It's fascinating to learn that all of these issues made this study more difficult, yet that everything turned out well. All of these issues were simply addressed. Many persons working in the project were sympathetic to the situation and went out of their way to assist.

\section{STATEMENT OF THE PROBLEM:}

1) Lack of unity among themselves: They sometimes cling to their independence out of fear of the risks or changes that come with them.

2) Workers' lack of confidence in their ability to provide and retain jobs: Workers do not believe they can provide and sustain jobs for themselves. In businesses owned by wealthy industrial or industry owners in the region. 
3) Management ignorance and the intricacy of business administration: in some circumstances, industry professionals lack management skills. They must either attend management training or live qualified managers, either temporarily or permanently, in order to obtain this.

4) Financial inequalities among workers: Because workers are assumed to be equal, inequalities in power, rank, and remuneration can cause friction.

5) Industrial workers have a poor degree of education and technical training.

\section{SIGNIFICANCE OF THE STUDY}

This study aims to demonstrate the importance and use of co-operative societies for the social and economic well-being of workers in industrial cooperatives. They play an important part in the state's price stabilisation of agricultural products.

Furthermore, they define the quality and price of things that are sold throughout the market, allowing companies to efficiently promote their goods. They reduce the excessiveness of middlemen in this way. In most states today, particularly Anambra, where practically every household, including the government, is pursuing self-sufficiency in agricultural product production, study is required to enable both the header and the government at large to understand the opportunities.

\section{VII.THE STUDY'S OBJECTIVE}

They work to attain the following objectives in the following order:

1) Determine the social and economic goals of workers in Inyaba co-operative.
2) To learn more about the specific roles and activities that Inyaba co-operative farms have played since their inception.

3) To identify the general issues that are preventing Inyaba co-operative farms ltd from running smoothly and efficiently.

4) To understand their future chances in light of Nigerians' low cooperative habits.

5) Finally, make suggestions that could be beneficial to the cooperative.

\section{CONCLUSION}

Cooperatives can provide significant, if not unique, contributions to the accomplishment of the economic components of future sustainable development goals, as evidenced by the numerous instances and arguments presented in this paper. The survey's findings indicate that, with the exception of a few areas, members' overall advantages and satisfaction levels are nearly attractive. It might also be argued that cooperatives play an important role in assisting women and youth in participating in social service, increasing their income, and acquiring their own resources. The contribution to women's and youth's empowerment Their participation in numerous social infrastructure initiatives, as well as their significance in the country's social and economic development, is evidence of their importance. The positive beginnings of their engagement in various social clubs were also discovered to be a sign of their role in each situation a facet of the country's development. 


\section{REFERENCES}

[1] SAGE Publication Ltd, India, Andy Field (2005), Discovering Statistics Using SPSS, Second Edition.

[2] Developing Financial Cooperatives Project (Financed by the Japan Fund for Poverty Reduction), Asian Development Bank (2006). 39481 is the project number.

[3] Addis Ababa: Central Statistics Agency, 472 statistical bulletin, Report on big and medium-scale manufacturing and electricity industries survey.

[4] Role of Cooperatives in Rural Development, the Case of South Nations Nationalities and People Region, Ethiopia, Nuredin Mohammed and Byeong Wan Lee (2015).

\section{Profile of the Author:}

1.

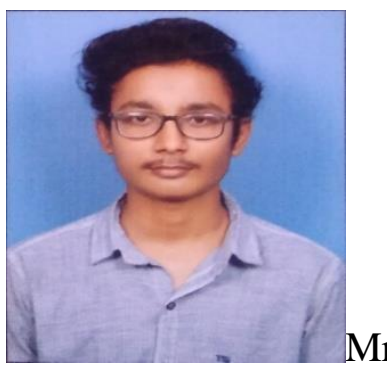

D. Sravan Kumar is a

B.E. Computer Science and Engineering student at Sri Chandrasekharendra SaraswathiViswa Mahavidyalaya regarded to be a university in Enathur, Kanchipuram, with a specialisation in Big Data Analytics.

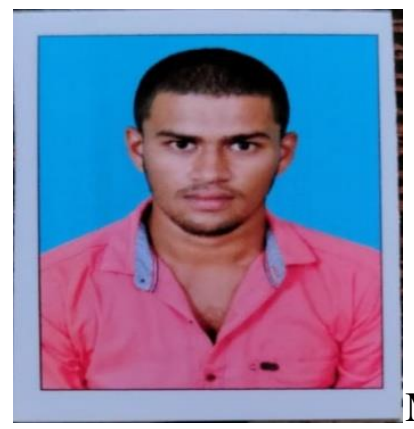

Mr. Ch. Manoj Kumar, B.E. Computer Science and Engineering, Sri Chandrasekharendra

SarswathiViswa Mahavidyalaya deemed to be university, Enathur, Kanchipuram, India His expertise is in big data analytics.

3.

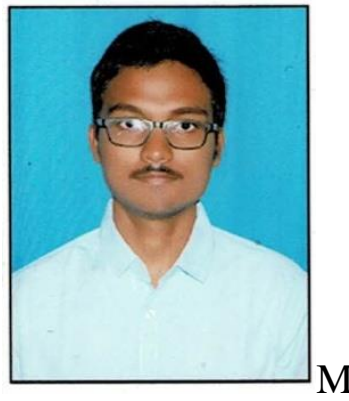

Computer Science and Engineering, sri Chandrasekharendra SarswathiViswa Mahavidyalata deemed to be university Enathur, Kanchipuram, India His expertise is in big data analytics.

4.

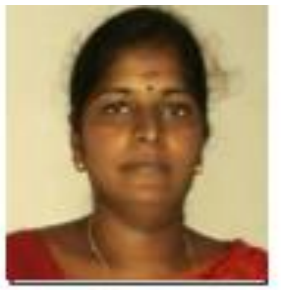

Assistant Professor of Computer Science and Engineering at Sri Chandrasekharendra SarswathiViswa Mahavidyalaya, a deemed university in Enathur, Kanchipuram. Her research interests include Software Engineering, Web Services, Knowledge Management, and Internet of Things. 